\title{
PROVOCĂRILE LIMBAJULUI \\ ÎN CODUL ADMINISTRATIV
}

DOI: 10.24193 /SUBBiur.65(2020).1.3

Data publicării online:

13.04.2020

\section{Ovidiu Podaru, Maria-Mihaela Pop*}

Rezumat: Intrat de curând în vigoare ${ }^{1}$, Codul administrativ a fost adoptat cu scopul declarat de a unifica reglementările din materia administrației publice, pentru a crea un cadru normativ închegat, venind în ajutorul particularilor, administrației publice, dar și al practicienilor. În acest sens, o parte semnificativă din prevederile codului sunt preluate identic din actele normative pe care le-a abrogat ${ }^{2}$, existând totodată și prevederi noi, unele dintre ele lăsând, din păcate, impresia unui cod adoptat în grabă. Fără a avea pretenția unei analize aprofundate asupra întregii reglementări, prezentul studiu urmărește să trateze unele dintre provocările pe care

* Ovidiu PoDARu este Conferențiar Universitar Doctor în cadrul Facultăţii de Drept a Universității Babeş-Bolyai, Departamentul de drept public, avocat în Baroul Cluj; contact: opodaru@yahoo.com; Maria-Mihaela Pop este student-doctorand, cadru didactic asociat al Facultății de Drept a Universității Babeș-Bolyai, Departamentul de drept public, avocat în Baroul Cluj, contact: pop mariamihaela@yahoo.com.

${ }^{1}$ Codul administrativ a intrat în vigoare prin adoptarea OUG: 57/2019, publicată în M.of.: 555 din 5 iulie 2019. Constituționalitatea codului a fost verificată în 12 februarie 2020, Curtea Constituțională emițând un comunicat de presă prin care a arătat că, raportat la criticile formulate, OUG: 57/2019 este în acord cu normele constituţionale.

${ }^{2}$ Un număr total de 99 de acte normative, cele mai cunoscute fiind L: 90/2001 „privind organizarea și funcționarea Guvernului României și a ministerelor”, L: 340/2004 „privind prefectul și instituția prefectului”, L: 215/2001 „a administrației publice locale”, L: 393/2004 „privind Statutul aleșilor locali”, OUG: 54/2006 „privind regimul contractelor de concesiune de bunuri proprietate publică” ori L: 188/1999 „privind Statutul funcționarilor publici”. 
le generează limbajul folosit în OUG: 57/2019. Între cele două extreme între care oscilează legiuitorul (fie un limbaj incomplet sau ambiguu, fie o supra-reglementare), problema cea mai relevantă, din punct de vedere al consecințelor pe care le poate produce, constă, probabil, în folosirea unor noțiuni deja consacrate din punct de vedere juridic, cu un sens total diferit (cum ar fi, de pildă, chestiunea competenței exclusive, delegate ori partajate, a capacității ori personalității juridice a autorităților publice). Pe lângă alterarea unor reguli sau instituții juridice deja consacrate, în cod se identifică pe alocuri și o dublare inutilă a unor termeni sau folosirea unor sintagme care pot schimba cu totul sensul avut în vedere de către legiuitor; în plus, noul act normativ rămâne restant (dacă nu cumva complică și mai mult lucrurile) în rezolvarea clară a unor probleme identificate anterior de doctrină și practica judiciară (cum ar fi, bunăoară, rolul secretarului în aprecierea legalității actelor autorităților administrației publice locale sau majoritatea necesară în ceea ce privește hotărârile legate de patrimoniul unității administrativ-teritoriale).

Cuvinte cheie: Codul administrativ, limbaj juridic, normă ambiguă, autorități publice centrale, autorități locale, descentralizare, capacitate administrativă, competențe exclusive, competențe delegate, competențe partajate, consilier local, oportunitate, ședință, majoritate absolută, majoritate calificată, Guvern, minister, prefect, contrasemnătură, contract de concesiune.

\section{THE CHALLENGES BROUGHT BY THE LANGUAGE USED IN THE NEW ROMANIAN ADMINISTRATIVE CODE}

Summary: Recently entered into force, the administrative code was adopted with the stated purpose of unifying the regulations in the field of public administration, in order to create a normative framework, coming to the aid of individuals, public administration, but also of practitioners. In this respect, a significant part of the provisions were taken identically from the normative acts that were repealed, while there are also new provisions, some of them leaving, unfortunately, the impression of a code adopted in haste. Without claiming a thorough analysis of the entire regulation, the present study aims to address some of the challenges brought by the language used in OUG: 57/2019. Between the two extremes among which the legislator oscillates (either an incomplete or ambiguous language, or an over-regulation), the most relevant problem, in terms of the consequences that it can produce, probably consists in using already legally established notions, with a totally different meaning (such as, for example, the question of competence - exclusive, delegated or shared, or of the capacity or legal personality of public authorities). In addition to altering some already established 
rules or legal institutions, the code identifies in some places an unnecessary duplication of terms or the use of phrases that can completely change the meaning envisaged by the legislator; furthermore, the new normative act remains in debt (if it does not complicate matters even more) to clarify some problems previously identified by the scholars and the judicial practice (such as, of course, the role of the secretary in assessing the legality of the acts of the local public administration authorities or the majority necessary regarding the decisions related to the patrimony of the administrative-territorial unit).

Keywords: Administrative code, legal language, ambiguous norm, central public authorities, local authorities, decentralization, administrative legal capacity, exclusive competence, delegated competence, shared competence, local elected councillor, opportunity, meeting, absolute majority, qualified majority, Government, Ministry, prefect, countersignature, administrative contract of concession.

La o primă lectură a Codului administrativ, primul gând care i-ar putea trece prin minte cuiva care și-a propus să fie atent la limbajul utilizat de „legiuitorul” nostru (cel de la Palatul Victoria, în acest caz particular) ar putea fi o parafrazare a unei anecdote deja clasice, al cărei final adaptat ar putea fi exprimat astfel: „Din perspectiva limbajului, acest Cod administrativ conține multe prevederi bune şi noi. Numai că cele bune ... nu sunt noi, iar cele noi ... nu sunt bune!"

Tocmai de aceea am găsit că nu ar fi tocmai lipsit de interes să trecem în revistă câteva prevederi (cel puțin) discutabile sub aspectul termenilor utilizați. Am încercat să le ordonăm în funcție de gravitatea consecințelor pe care le produc: de la lipsa unor asemenea consecințe, până la unele efecte juridice grave. Dar, să le luăm pe rând:

\section{Limbajul redundant}

Cele ce urmează sunt exemple benigne, care nu par a avea nicio consecință juridică, cu excepția îngrijorării că legiuitorul nostru nu cunoaște 
prea bine noțiunile juridice, de vreme ce utilizează adesea formule (aproape) pleonastice. Sunt cel puțin două asemenea asocieri de termeni pe care se pare că le preferă:

\section{1 „Competența și atribuțiile” (unui organ administrativ)}

Această asociere se regăsește frecvent în prevederile Codului : art. 84 alin. (4) şi art. 87 alin. (2) sunt doar două asemenea exemple. Mergând mai departe cu forțarea limbajului, legiuitorul stabileşte prin art. 129 alin. (7) că „În exercitarea atribuțiilor prevăzute la alin. (2) lit. d), consiliul local asigură, potrivit competenței sale și în condițiile legii [s.n. Ov.P., M.M. P.], cadrul necesar pentru furnizarea serviciilor publice de interes local privind: (...)”, adăugând încă o sintagmă oarecum inutilă („,̂n condițiile legii”) acestei asocieri nefericite de termeni.

Astfel, fiind o condiție de valabilitate externă a actului administrativ, competența organelor administrative s-a raportat mereu la totalitatea atribuțiilor, circumscrise în spațiu, timp și cu privire la persoane3. Ideea s-a păstrat și în reglementarea din Codul administrativ, competența fiind definită în partea generală drept „ansamblul atribuțiilor stabilite de lege”. Cu toate acestea, cele două noțiuni sunt adesea folosite împreună, sugerând (în mod eronat) că ele nu ar fi sinonimice. Totuși, exprimarea pleonastică nu pare a avea vreo consecință juridică, însă sugerează în mod clar fie neatenția legiuitorului, fie o lipsă a stăpânirii unor noțiuni juridice pe care chiar el le-a definit.

3 Ov. PodARU, Drept administrativ. Vol. I. Actul administrativ. Repere pentru o teorie altfel, Ed. Hamangiu, București, 2010, p. 83. 


\section{2 „Necesitatea și oportunitatea” (emiterii unui act administrativ)}

Şi această asociere de termeni o regăsim în cel puțin trei texte de lege diferite: art. 50 alin. (2), art. 57 alin. (5) și art. 240 alin. (2) C.adm., în toate aceste situații fiind afirmată ideea că atât necesitatea cât și oportunitatea emiterii unui act administrativ este stabilită în mod exclusiv de emitentul acestuia.

Iată deci că, cu privire la cauza actului administrativ, codul introduce o noțiune nouă - aprecierea „necesității” adoptării acestuia - noțiune care, fără a fi definită în partea generală, nu este folosită niciodată în mod individual, ci întotdeauna doar împreună cu oportunitatea adoptării lui, sugerând astfel că organul administrativ competent ar trebui să aibă în vedere la emiterea actului două chestiuni diferite: pe de o parte, caracterul necesar și, pe de altă parte, caracterul oportun al emiterii actului. Cu toate acestea, niciunul dintre textele amintite nu atribuie propriu-zis un alt înțeles noțiunii de necesitate, altul decât puterea de apreciere pe care o are administrația de a alege între două sau mai multe conduite posibile ${ }^{4}$ (adică exact oportunitatea emiterii actului administrativ). De altfel, atât doctrina ${ }^{5}$, cât şi jurisprudența ${ }^{6}$,

\section{Ibidem, p. 237.}

5 D. Apostol Tofan, Drept administrativ. Volumul II, Ediția 4, Ed. C.H. Beck, București, 2017, p. 30-35. A se vedea, de asemenea, și G. BogASIU, Competența autorității emitente, condiție de validitate a actului administrativ. Caracterul autonom al competenței, în Revista Română de Jurisprudență nr. 4 din data de 30 aprilie 2011: „Caracterul autonom al competenței presupune, după cum subliniază doctrina de specialitate, dreptul titularului de a-și exercita atribuțiile și, implicit, obligația celorlalte persoane de a asigura independența operativă necesară realizării acesteia și de a nu se substitui titularului competenței, chiar dacă acesta este subordonat ierarhic".

6 ÎCCJ, s.c.a.f, dec.civ.: 2702/2015, disponibilă la www.sintact.ro: „Dreptul de: apreciere semnifică posibilitatea autorității administrative de a decide asupra oportunității unei atitudini sau acțiuni concretizată ulterior în emiterea/ adoptarea unui act administrativ care prin efectele produse va interveni asupra realității înconjurătoare în sensul modificării acesteia, 
atunci când tratează oportunitatea adoptării actului au în vedere și dacă actul administrativ este sau nu necesar, raportat la interesul public. Prin urmare, în realitate, necesitatea se identifică cu oportunitatea, fiind inutilă introducerea acestei noi sintagme în Codul administrativ.

Chiar dacă la prima vedere par inofensive, aceste asocieri de termeni ar putea fi speculate în contextul unui litigiu legat de actul administrativ, încercându-se, cu ajutorul lor, sustragerea unui act administrativ de la controlul instanței specializate de contencios administrativ.

\section{Adevărul evident („Iarna nu-i ca vara”)}

Şi aici merită remarcate cel puțin două prevederi legale care, pe lângă truismul afirmat, conțin și câte o ambiguitate care complică lucrurile:

\subsection{Consilierii și ședințele de consiliu local: prezență versus absență}

Potrivit art. 137 alin. (2) C.adm., „Prezența consilierilor locali la ședință este obligatorie, cu excepția cazului în care aceștia absentează motivat [s.n. Ov.P., M.-M. P.].” Pe lângă inexactitatea în exprimare (lipsa motivată este, în mod evident, o situație de absență, iar nu una de prezență fără caracter obligatoriu), prevederea nu pare să aibă vreun sens, raportat la modul evident în care a fost formulată: ar fi fost mult mai clar dacă, într-o a doua teză s-ar fi prevăzut faptul că în situația unei absențe motivate consilierului în cauză nu i se vor aplica sancțiunile prevăzute de lege.

modificare ce ar trebui să fie întotdeauna în conformitate cu interesul general și cu respectarea drepturilor particularilor. Curtea a mai evidențiat că oportunitatea actului administrativ este o consecinţă a dreptului de apreciere al autorităților publice și poate face obiectul controlului judecătoresc în limitele mai sus menționate.” 
În plus însă, acest text aparent inofensiv, are o continuare periculoasă: „Absența este considerată motivată dacă se face dovada că aceasta a intervenit din cauza: [...] e) alte situații prevăzute în regulamentul de organizare și funcționare a consiliului local".

Spre deosebire de reglementarea anterioară ${ }^{7}$, când toate cazurile în care absența era considerată motivată erau stabilite prin regulamentul de organizare şi funcționare a consiliului local (fapt de asemenea criticabil), în prevederile analizate ale codului sunt enumerate mai multe cauze în care absența este justificată (boală care a necesitat spitalizarea sau o stare de sănătate pentru care s-a eliberat certificat de concediu medical, deplasare în străinătate, evenimente de forță majoră), urmând ca acestea să poată fi completate prin hotărâre de consiliu local, odată cu adoptarea regulamentului propriu. Se recunoaşte astfel că, pe lângă cauzele obiective descrise în textul legal, fiecare consiliu local ar avea o putere discreționară de a stabili și alte situații care să-i scutească pe consilieri de sancțiunile legale; situații care sunt, astfel stabilite... chiar de cei pasibili de sancțiune! Ca să nu mai vorbim de inegalitatea de statut juridic (din această perspectivă) dintre consilierii aparţinând unor consilii diferite! Astfel, având în vedere că, potrivit art. 73 alin. (3) lit. o) din Constituție, organizarea și funcționarea administrației publice este de domeniul legii organice, prevederile citate sunt suspecte de neconstituționalitate.

\footnotetext{
7 Art. 40 alin. (2) din L: 215/200: „[...] Cazurile în care absența este motivată se stabilesc prin regulamentul de organizare și funcționare a consiliului local. Consilierul local care absentează nemotivat de două ori consecutiv este sancționat, în condițiile regulamentului de organizare și funcționare a consiliului local.”
} 
2.2 Criteriile de atribuire a concesiunii și ponderea acestora: o problemă de matematică

Potrivit art. 340 alin. (2) C. adm. (care reglementează criteriile de atribuire a contractului de concesiune de bunuri proprietate publică): „Ponderea fiecărui criteriu se stabilește în documentația de atribuire şi trebuie să fie proporțională cu importanța acestuia apreciată din punctul de vedere al asigurării unei utilizări/exploatări raționale și eficiente economic a bunului închiriat. Ponderea fiecăruia dintre criteriile prevăzute la alin. (1) este de până la 40\%, iar suma acestora nu trebuie să depășească 100\%.”

Un truism și o ambiguitate. Pe de o parte, este evident faptul că însăși noțiunea de „pondere” reprezintă procentul care exprimă „greutatea” (importanța) unui anumit criteriu în ansamblul general, importanță raportată (așa cum și sugerează etimologia - „cent”) la 10o! În consecință nici nu se poate altfel: suma ponderii tuturor criteriilor trebuie să fie exact 10o. Pe de altă parte însă, exprimarea eliptică folosită de legiuitor sugerează că suma acestora poate să fie mai mică de 100\%, ambiguitate care, în mod evident, conduce la o concluzie juridică (și matematică) greșită ${ }^{8}$.

\section{Limbajul incomplet/lacunar (o tăcere care nu este de aur)}

În cele ce urmează vom analiza diverse lacune: legiuitorul omite fie unele noțiuni (termeni, cuvinte), ori trăsături ale acestora, fie idei, explicații etc. care lasă în urmă un semn de întrebare.

\footnotetext{
8 Astfel, într-o ipoteză în care s-ar stabili că sunt două criterii care se vor aplica într-o anumită situație, chiar dacă ponderea unui criteriu ar fi apreciată ca fiind de $25 \%$, iar a altui criteriu tot de $25 \%$, în realitate, fiecare dintre acestea va avea o pondere de $50 \%$.
} 
3.1 Președintele consiliului județean: între „autoritate” și „ales”

Potrivit art. 3 C.adm., „Autorităţile administrației publice locale sunt: consiliile locale, primarii și consiliile județene”. Inspirat din prevederile art. 121-122 din Constituție, care nu vorbește defel despre președintele consiliului județean, textul pare a intra într-o contradicție (măcar parțială) cu prevederile art. 107 alin. (2) C.adm. care stabilește expres că președintele consiliului județean conduce consiliul județean. Chiar dacă nu știm dacă este vorba despre o omisiune voită ori accidentală, consecințele acesteia pot fi semnificative în materia contenciosului administrativ. Un exemplu ar putea fi dat, bunăoară, cu privire la limitele controlului de tutelă exercitat de prefect; căci, potrivit art. 3 alin. (1) din Legea nr. 554/2004, acesta poate ataca direct în fața instanței de contencios administrativ actele emise de autorităţile administrației publice locale. Or, dacă președintele consiliului județean nu este enumerat printre autoritățile administrației publice locale, ar părea că dispozițiile președintelui consiliului județean nu pot face obiectul contenciosului declanșat de către prefect. Apoi, dacă președintele consiliului județean nu e autoritate publică, asta înseamnă automat că el nu are calitate procesuală pasivă în contenciosul administrativ, cel vătămat trebuind să se îndrepte fie împotriva consiliului județean (considerând că dispoziția președintelui este, în realitate, actul consiliului județean), fie împotriva județului, în temeiul teoriei pe care o vom dezvolta succint la sfârșitul acestui studiu.

\subsection{Esența ideii de „majoritate calificată”}

Potrivit art. 5 alin. (1) lit. dd) C.adm., prin majoritate calificată se înțelege „primul număr natural care este mai mare decât valoarea numerică 
rezultată în urma aplicării fracției/procentului stabilite/stabilit prin lege la totalul membrilor organului colegial stabilit în condițiile legii”.

Tradițional, în doctrină9, majoritatea absolută este reprezentată de votul majorității membrilor în funcție ai organului administrativ, pe când cea calificată reprezintă orice majoritate mai mare decât cea absolută (2/3, 3/4, 3/5, 4/5 sau orice altă fracție mai mare decât jumătate constituie o asemenea majoritate, dacă legea o prevede în mod expres $\left.{ }^{10}\right)$. Partea generală a Codului administrativ are o exprimare mai „matematică” care, chiar dacă în aparență păstrează sensul primar al celor două noțiuni, nu indică o idee esențială: faptul că majoritatea calificată trebuie să fie mai mare decât majoritatea absolută. Astfel, votul necesar în cazul majorități absolute (art. 5 lit. cc) este primul numărul strict mai mare decât $1 / 2$ din numărul membrilor organului colegial stabilit în condițiile legii (jumătate plus unu din numărul total al membrilor în funcție). În cazul majorităţii calificate, raportarea nu se mai face la 1/2 din numărul total al membrilor în funcție, ci la fracția/procentul calculat din numărul total al membrilor, fără a se stabili imperativ că această fracție/procent trebuie să fie mai mare decât $1 / 2$ din numărul total (căci atunci am avea fie o majoritate absolută fie nu ar mai exista majoritate raportată la totalitatea membrilor). Prin urmare, pentru înțelegerea corectă a noțiunii de „majoritate calificată”, prevederile Codului administrativ nu sunt suficiente, fiind necesar a se face apel la ideea de esență a acestei noțiuni, așa cum a fost ea conturată prealabil adoptării codului.

\footnotetext{
9 D. Apostol Tofan, op. cit., p. 40; V. Vedinaș, Drept administrativ. Ediția a X-a revăzută şi actualizată, Ed. Universul Juridic, București, p. 217.

${ }^{10}$ I. IOVĂNAȘ, Drept administrativ, Ed. Servo-Sat, Arad, 1997, p. 44.
} 


\subsection{Secretariatul General al Guvernului și natura sa juridică}

Potrivit art. 19 C.adm., „Aparatul de lucru al Guvernului este alcătuit din Secretariatul General al Guvernului, Cancelaria Prim-ministrului, aparatul propriu de lucru al viceprim-ministrului, departamente şi alte structuri organizatorice $\mathrm{cu}$ atribuții specifice stabilite prin hotărâre a Guvernului”.

Spre deosebire de reglementarea anterioară ${ }^{11}$, codul nu mai arată în prezent nici măcar dacă secretariatul general are un buget propriu (care ar sugera, deci, și existența unui patrimoniu). Astfel, voit sau nu, se omite a se tranşa problema personalităţii sale juridice, specificându-se doar, în art. 20 alin. (4), că organizarea și atribuțiile sale vor fi stabilite prin hotărâre de Guvern $^{12}$. Lipsa de claritate a legiuitorului poate avea efecte asupra calității procesuale pasive într-un litigiu de contencios administrativ: în lipsa personalităţii juridice, Secretariatul General al Guvernului nu poate sta în judecată ca pârât, într-un petit de despăgubire formulat, atunci când reclamantul se consideră vătămat printr-un act sau un refuz nejustificat al Guvernului (care nici el nu are capacitate juridică deplină). Prin urmare, a lăsa chestiunea personalității juridice a Secretariatului la mâna guvernului, care o

\footnotetext{
${ }^{11}$ Art. 21^1 din L: 90/2001: „Aparatul propriu de lucru al viceprim-ministrului este structură fără personalitate juridică, finanțată prin bugetul Secretariatului General al Guvernului, condusă de viceprim-ministru."

12 În prezent, personalitatea juridică a „Secretariatului General al Guvernului” este stabilită de art. 1 alin. (1) din Hotărârea 137/2020 privind organizarea, funcţionarea și atribuțiile unor structuri din cadrul aparatului de lucru al Guvernului publicată în M.of.: 123 din data de 17 februarie 2020: „Secretariatul General al Guvernului se organizează și funcționează ca instituție publică cu personalitate juridică [s.n. Ov.P., M.-M. P.] în subordinea primministrului, având rolul de a asigura derularea operațiunilor tehnice și de strategie aferente actelor de guvernare, rezolvarea problemelor organizatorice, juridice, economice și tehnice ale activității Guvernului, ale prim-ministrului, precum şi reprezentarea Guvernului şi a primministrului în fața instanțelor judecătorești."
} 
poate recunoaște ori, după caz, desființa, prin hotărâre, echivalează cu a permite unei părți dintr-un litigiu de a stabili, chiar în timpul unui proces, în caz de nevoie, dacă acțiunea în daune a reclamantului a fost sau nu corect introdusă ${ }^{13}$.

\subsection{Actele miniștrilor - între redundanță și omisiune}

Potrivit art. 57 alin. (1) și (2) C.adm., ,În exercitarea atribuțiilor ce îi revin, ministrul emite ordine și instrucțiuni cu caracter normativ sau individual [s.n. Ov.P., M.-M. P.]. Prin ordine se pot aproba norme metodologice, regulamente sau alte categorii de reglementări care sunt parte componentă a ordinului prin care se aprobă”.

Una dintre problemele care puteau fi tranşate odată cu intrarea în vigoare a Codului administrativ o reprezintă diferența dintre cele două categorii de acte administrative, „ordine” respectiv „instrucțiuni”, însă legiuitorul a ratat această şansă. Astfel, deşi se menționează expres că un ministru poate emite ordine şi instrucţiuni, pe de o parte ambele pot avea atât caracter normativ, cât şi individual, iar, pe de alta, textul de lege nu specifică decât obiectul de reglementare al ordinelor, nu și al instrucțiunilor. Așadar, nici la acest moment, încă nu suntem măcar la nivelul dreptului administrativ interbelic, când diferența era stabilită clar: instrucțiunile sunt actele cu caracter normativ, pe când ordinele sunt actele individuale ale miniștrilor.

\footnotetext{
13 Bunăoară, dacă textul art. 1 alin. (1) din HG: 137/2020 citat mai sus ar fi abrogat printr-o altă hotărâre de guvern cu puțin timp înainte de pronunțarea hotărârii definitive, este evident că petitul în daune va fi respins ca inadmisibil de vreme ce pârâtul împotriva căruia a fost introdus şi-a pierdut chiar calitatea de subiect de drept civil; sau, chiar dacă nu ar fi, hotărârea pronunțată nu ar putea fi dusă la îndeplinire.
} 
3.5 Din nou despre prezențe și absențe: un articol gigantic, dar mai greu inteligibil

Potrivit art. 116 alin. (7) și (8) C.adm., ,În cadrul celei de a doua ședințe pot depune jurământul consilierii locali validați care au absentat de la prima şedință [s.n. Ov.P., M.-M. P.] şi supleanții ale căror mandate au fost validate în condițiile art. 119 şi consilierii locali validaţi în condițiile art. 114 alin. (6) și (7) și care nu au fost convocați la prima ședință de constituire a consiliului local. Prin excepție de la dispozițiile alin. (7) consilierul local declarat ales care nu a putut depune jurământul, ca urmare a absenței pentru motive temeinice [s.n. Ov.P., M.-M. P.], poate depune jurământul în cadrul primei ședințe a consiliului local [s.n. Ov.P., M.-M. P.]. Sunt considerate motive temeinice spitalizarea sau imobilizarea la pat, dovedită prin certificat medical, ori situații precum deplasarea în străinătate în interes de serviciu, evenimente de forță majoră, cum ar fi inundații sau alte catastrofe care au împiedicat deplasarea, deces în familie ori alte situații similare.

Textul art. 116 este greu de urmărit pentru oricine: sunt multe alineate, fraze lungi şi multiple în aproape fiecare alineat. Așa că nu e deloc greu ca cititorului să-i scape ceva: mai întâi se vorbește despre prima şedință şi cei care absentează de la aceasta; apoi de a doua şedință şi cei care nu pot depune jurământul nici în acest moment; şi în fine, legiuitorul pare a reveni la prima şedință, iar ideea poate genera nedumerire. În realitate, analizând titlul articolului - ședințele privind ceremonia de constituire a consiliului local - se poate observa că primele două ședințe despre care vorbește art. 116 sunt ședințe de constituire a consiliului local, alin. (7) exprimând regula potrivit căreia consilierul ales care a absentat de la prima ședință, poate să depună jurământul cu acel prilej. Prin excepție, în măsura în care acesta lipsește, din motive temeinice, și de la această ședință, va putea depune jurământul, însă 
nu la prima ședință de constituire - nici nu ar mai avea cum să procedeze astfel - ci la prima ședință obișnuităa ${ }^{14}$ a consiliului local. Deși, finalmente, după analizarea prevederilor referitoare la ședințele consiliului local, se poate determina care a fost intenția legiuitorului, pentru a se respecta cerințele de claritate, se putea specifica expres fie că primele două ședințe sunt ședințele de constituire a consiliului local, fie că prima ședință, menționată în alin. (8) se referă la prima ședință a consiliului local, legal constituit.

\section{6 Și din nou la majoritate ... de această dată la cea absolută}

Potrivit art. 139 alin. (3) C.adm., „Se adoptă cu majoritatea absolută prevăzută la art. 5 lit. cc) a consilierilor locali în funcție următoarele hotărâri ale consiliului local: [...] g) hotărârile privind administrarea patrimoniului”.

Spre deosebire de prevederea anterioară ${ }^{15}$, când toate hotărârile care vizau patrimoniul se adoptau cu majoritatea calificată de două treimi din numărul total al consilierilor locali în funcție, art. 139 C.adm. le scindează: pe de o parte, cele privind dobândirea sau înstrăinarea dreptului de proprietate în cazul bunurilor imobile se adoptă cu o majoritate calificată; pe de alta, cele legate de „administrarea patrimoniului” se adoptă cu majoritate absolută. Intenția legiuitorului ${ }^{16}$ a fost, probabil, și aceea de a înlătura o formulare imprecisă - „hotărârile privind patrimoniul” - care a creat un câmp larg de interpretare și care, în unele situații, nu justifica aplicarea majorității calificate.

$\mathrm{Cu}$ toate că problema semnalată era una reală, textul generând numeroase litigii, tocmai raportat la caracterul vag al formulării, nici

\footnotetext{
14 Art. 133 C.adm.

15 Art. 45 alin. (3) din L: 215/2001.

${ }^{16}$ A se vedea în acest sens V. VEDINAȘ, op. cit., pag. 98.
} 
sintagma „administrarea patrimoniului” nu este suficient de clară și nu rezolvă în totalitate problema vechii reglementări.

Astfel, pe de o parte, codul nu arată ce fel de hotărâri pot fi calificate drept hotărâri privind administrarea patrimoniului, Consiliul local putânduși aroga libertatea de a stabili ce decizii pot fi calificate drept acte de administrare sau, dimpotrivă, acte de dispoziție, aşa cum sunt ele definite şi în dreptul civil. Întrucât cele două noțiuni sunt împrumutate din Codul civil, iar potrivit art. 1 alin. (2) prevederile Codului administrativ se completează cu cele ale Codului civil, trebuie amintită discuția pe care o face doctrina în dreptul comun ${ }^{17}$ : o anumită operațiune juridică se încadrează în categoria actelor de administrare sau a celor de dispoziție nu neapărat după natura

\footnotetext{
17 M. NicolaE, Drept civil. Teoria generală. Vol. II, Teoria drepturilor subiective civile, Ed. Solomon, București, 2018, p. 325-326. Autorul arată că, deși potrivit literaturii de specialitate, actele de gestiune sunt clasificate în acte de conservare, de administrare și de dispoziție, având în vedere importanța sau gravitatea actului, le clasifică în acte de conservare și acte de administrare. Astfel, arată că actul de conservare acel act juridic care are ca efect preîntâmpinarea pierderii unui drept subiectiv civil (asigurarea bunului, întreruperea unei prescripții prin acțiunea în justiție, înscrierea unei ipoteci sau a unui privilegiu în registrele de publicitate), iar actul de administrare este acel act juridic civil prin care se realizează o normală punere în valoare a unui bun ori a unui patrimoniu sau a unei mase patrimoniale, după caz. Aceste din urmă acte le subclasificată în acte de administrare simplă (actul juridic prin care se realizează exploatarea bunului sau a patrimoniului de către proprietarul bunului direct sau prin intermediul altei persoane - închirierea sau arendarea bunului, investirea sumelor de bani în titluri de valoare, înstrăinarea bunurilor devenite nefolositoare sau care sunt supuse pieirii și stricăciunii ori sunt necesare conservării bunurilor, achitării datoriilor sau menținerii modului de folosință potrivit cu destinația obișnuită a bunurilor, înstrăinarea fructelor), respectiv acte de administrare deplină (actul juridic civil care are ca rezultat ieșirea din patrimoniu a unui bun sau drept - actele de înstrăinare propriu-zise ori grevarea unui bun cu o sarcină reală uzufruct, ipotecă, gaj, cum ar fi, spre exemplu, vânzarea și donația, constituirea unui drept de folosință limitată ipoteca convențională, contractul de administrare a bunurilor comune). Același criteriu, al importanței sau gravității actului este folosit și de alți autori: G. BoroI, L. STĂNCIUlESCU, Instituții de drept civil în reglementarea noului Cod Civil, Ed. Hamangiu, București, 2012, p. 83; I. Reghini, Ș. Diaconescu, P. VAsilescu, Introducere în dreptul civil. Vol. 2, Ed. Sfera Juridică, Bucureşti, 2007, p. 128-131.
} 
actului, ci mai degrabă după ponderea obiectului material al actului juridic în ansamblul patrimoniului dispunătorului. Prevederile codului nu fac însă o asemenea distincție, rămânând deci ca soluția la neclaritatea normei să își găsească rezolvarea în dreptul civil.

Pe de altă parte, din perspectiva importanței concrete a unei hotărâri a consiliului, raportat la impactul pe care l-ar avea asupra interesului public, aceasta ar putea fi mai mare la un act de administrare a patrimoniului (impunându-se astfel o majoritate calificată), decât la un act de dispoziție. De pildă, hotărârea de a concesiona un bun din proprietatea publică a unei unităţi administrativ-teritoriale pe o durată de 49 de ani, chiar dacă se încadrează formal în categoria actelor de administrare a patrimoniului, are o însemnătate mai mare asupra domeniului public, decât o hotărâre care vizează vânzarea unui bun din domeniul privat al unității administrativ teritoriale care nu mai este util interesului public. Așadar, categoria hotărârilor adoptate de consiliul local, cu privire la patrimoniul unităţii administrativ-teritoriale nu e scutită nici acum de o doză semnificativă de echivoc.

\section{Limbajul ambiguu. Câteva situații, cauze și consecințe posibile}

Exprimarea neclară regăsită în unele texte de lege a constituit întotdeauna o sursă de dispute. Condamnat adesea de către Curtea de la Strasbourg, care reclamă întotdeauna respectarea calităţii dreptului ca o componentă indispensabilă a principiului securității raporturilor juridice ${ }^{18}$,

\footnotetext{
${ }^{18}$ A se vedea în acest sens cauza PăDURARU C. ROMÂNIA, publicată în M.of. partea I, nr. 514 din 14 iunie 2006, pg. 92, 99.
} 
un limbaj juridic ambiguu nu poate fi, desigur, de dorit. În Codul administrativ am găsit însă asemenea situații, grupate în funcție de unele criterii evidențiate în titlurile paragrafelor care urmează.

\subsection{Limbajul (aparent) clar, dar care alterează o regulă/instituție juridică preexistentă (și consacrată): despre joaca Guvernului de- a organul ierarhic superior}

Potrivit art. 26 alin. (2) C.adm., ,În exercitarea controlului prevăzut la alin. (1), Guvernul poate solicita revocarea [s.n. Ov.P., M.-M. P.] actelor administrative nelegale, netemeinice sau inoportune emise de autorităţile prevăzute la alin. (1) care nu au intrat în circuitul civil și nu au produs efecte juridice şi care pot leza interesul public".

\section{a) Are Guvernul un veritabil control ierarhic la dispoziție?}

Văzut ca o atribuție a Guvernului ${ }^{19}$, controlul ierarhic exercitat de acesta (și care reflectă rolul său de conducător general al administrației publice) este reglementat de prevederile art. 26 alin. (1) din C.adm. În exercitarea acestui tip de control, potrivit prevederilor mai sus citate, Guvernul „poate solicita revocarea actelor administrative" emise de organele inferioare. La prima vedere, textul ar părea că enunță una din consecințele prerogativei de control ierarhic asupra actelor ${ }^{20}$ autorităților din subordinea sa, prerogativă pe care o

19 Potrivit art. 25 pct. l) C.adm., Guvernul „controlează activitatea ministerelor și a celorlalte
organe de specialitate din subordinea sa”. Şi acest text pare a fi lacunar, având în vedere că din
enumerare este exclus prefectul, un organ ierarhic inferior Guvernului. Dimpotrivă, acesta este
amintit în prevederile art. 26 alin. (1), când sunt reluate organele administrative asupra cărora
Guvernul exercită un asemenea control.
${ }^{20}$ Controlul ierarhic asupra actelor conferă Guvernului puterea de revocare, suspendare și
chiar de reformare a actelor administrative (cu excepția situațiilor de competență exclusivă a
organului inferior într-un anumit domeniu, când această putere de reformare este înlocuită cu
puterea de injoncțiune). În ipoteza existenței doar a unei asemenea puteri de injoncțiune, dacă 46 
are Guvernul: puterea de revocare a acestora. Din formularea textului reiese însă că, la fel ca un simplu particular care s-ar putea considera vătămat de un asemenea act și care recurge la procedura administrativă prealabilă, și organul conducător al administrației publice poate doar să solicite revocarea unui asemenea act, nu să o și dispună.

Consecințele acestei formulări se produc în primul rând în ceea ce privește limitele controlului ierarhic: atribuția Guvernului se transformă dintr-una decizională (prerogativa de a dispune revocarea), într-una consultativă $^{21}$ (prerogativa de a propune revocarea). Cu alte cuvinte, în realitate, Guvernul nu ar mai avea un veritabil control ierarhic asupra actelor organelor din subordinea sa. Şi, cum textul nu clarifică cine ar avea în această situație competența emiterii actului de revocare, singura variantă este aceea în care ea aparține organului inferior care l-a emis. Astfel, instituția recursului ierarhic ar fi, din această perspectivă, lipsită de efecte pentru particularul vătămat de act, din moment ce oricum Guvernul poate emite doar o „opinie” în ce privește scoaterea actului din ordinea juridică. Așadar, din perspectiva prevederilor art. 7 din Legea nr. 554/2004, un asemenea recurs ierarhic, chiar dacă e posibil din punct de vedere juridic, este ineficient pentru particular, prelungind în mod inutil momentul introducerii cererii de chemare în judecată. De exemplu, persoana vătămată printr-un ordin al unui ministru nu

actul (ilegal sau inoportun) nu este reformat de bună voie de organul inferior la cererea expresă a organului superior, acesta din urmă poate trece la exercitarea controlului ierarhic asupra persoanelor, care constă în general în posibilitatea (discreționară sau nu, în funcție de criteriul de numire în funcție, reglementat de lege) organului superior de numire, mutare, sancţionare şi chiar revocare din funcție a organului inferior (în cazul nostru ministru, secretar de stat ori prefect).

${ }^{21}$ Propunerea este doar consultativă, iar nu conformă căci, potrivit textului de lege, Guvernul poate să solicite, fără ca solicitarea să fie obligatorie pentru organul emitent (pentru detalii cu privire la clasificarea propunerilor în facultative, consultative și conforme a se vedea Ov. Podaru, Actul administrativ, op.cit., p. 175-179). 
va mai avea interes să solicite revocarea actului Guvernului - deși este o variantă permisă de lege - fiind de preferat să aleagă calea recursului grațios, singura eficientă juridic în acest caz.

Este interesant de analizat cum s-ar corela acest text cu prevederile art. 275 alin. (8) C.adm. potrivit cărora „Ministrul care coordonează instituția prefectului poate propune Guvernului [s.n. Ov.P., M.-M. P.] revocarea ordinelor emise de prefect care au caracter normativ sau a celor prevăzute la alin. (2) şi (6), dacă le consideră nelegale sau netemeinice, în cazul în care acestea nu au intrat în circuitul civil și nu au produs efecte juridice și pot leza interesul public". Cu alte cuvinte, în cazul ordinelor emise de prefect, Ministrul poate să solicite Guvernului revocarea actului, dar acesta din urmă, potrivit art. 26 alin. (2) din acelaşi act normativ, nu poate decât să solicite prefectului să-şi revoce propriul act.

Un alt semn de întrebare pe care-l ridică sintagma „poate solicita” se întrevede în sfera consecințelor refuzului de revocare al actului; având în vedere că textul nu atribuie un caracter obligatoriu acestei propuneri, singura variantă pe care ar avea-o Guvernul la dispoziție ar fi aceea de a recurge la controlul ierarhic asupra persoanelor: dacă organul inferior nu răspunde favorabil solicitării de revocare venite din partea acestuia, Guvernul ar putea dispune aplicarea unei sancțiuni (politice, în cazul lipsei unei prevederi legale în acest sens) sau chiar revocarea din funcţie a organului inferior.

Textul este criticabil aşadar din perspectiva limitării - voite sau nu a competenței de revocare a actelor organelor inferioare, fiind de esența controlului ierarhic ca Guvernul să poată dispune, nu doar să propună revocarea.

b) Când s-ar putea dispune/propune revocarea unui act administrativ? Elementul nou introdus de art. 26 alin. (2) C.adm. în 
materie de motive care ar putea sta la baza revocării este cel care ține de „netemeinicie”. Până la momentul adoptării Codului administrativ, limitele controlului ierarhic erau clare: spre deosebire de controlul exercitat de instanțele de judecată sau controlul de tutelă, unde se poate verifica doar legalitatea actului administrativ, prerogativele de control ierarhic asupra actelor sunt extinse: atât asupra legalitățiii, cât şi asupra oportunităţii actelor administrative. Codul administrativ pare însă că extinde sfera motivelor de revocare, introducând în plus, pe lângă cele două motive consacrate deja în doctrină şi jurisprudență, şi noțiunea de „netemeinicie”.

Sintagma este folosită de legiuitor în trei prevederi distincte: (i) art. 26 alin. (2) - cazurile în care Guvernul poate să propună revocarea unui act administrativ emis de un organ inferior; (ii) art. 275 alin. (8) - cazurile în care actele prefectului pot fi revocate de către Guvern; (iii) art. 527 alin. (1) ${ }^{22}-$ motivele pe care le poate invoca funcționarul al cărui raport de serviciu a încetat, în fața instanței de contencios. Elementul comun al acestor texte este că ele încadrează netemeinicia în sfera viciilor de care este afectat actul care riscă să fie propus spre revocare, revocat sau anulat de către instanța de contencios administrativ.

Fără a fi explicată în vreun fel în partea generală, raportat la condițiile de valabilitate ale actului administrativ, temeinicia sugerează o analiză a motivelor care au stat la baza emiterii, adică a condiției oportunității actului

22 Potrivit art. 527 C.adm. (Anularea actului administrativ de încetare a raportului de serviciu), alin. (1), „În cazul în care raportul de serviciu a încetat din motive pe care funcționarul public le consideră netemeinice sau nelegale, acesta poate cere instanței de contencios administrativ anularea actului administrativ prin care s-a constatat sau s-a dispus încetarea raportului de serviciu, în condițiile și termenele prevăzute de legea contenciosului administrativ [...]”. Cu precizarea că în acest text de lege am putea considera netemeinicia un sinonim al inoportunității, lucru pe care, în mod riguros, nu-l putem face și cu privire la art. 26 alin. (2) C.adm., unde şi termenul de „inoportunitate” este utilizat în mod distinct. 
administrativ ${ }^{23}$. Și care ar fi atunci diferența între temeinicie și oportunitate? Din punctul nostru de vedere, o astfel de diferență nu există, cele două noțiuni trebuind să fie considerate sinonime. Cu toate acestea, având în vedere că art. 26 alin. (2) le consideră noțiuni diferite, acest aspect poate da naștere unor probleme în aplicarea sa concretă, textul putând fi speculat atât de organele administrative (care ar putea imagina o nouă categorie de motive de refuz de emitere a unui act administrativ), dar şi de către justițiabili (care ar putea să forțeze limitele cenzurii instanței de contencios administrativ prin crearea unei categorii incerte a motivelor de temeinicie).

c) Când este interzisă revocarea unui act administrativ? În ceea ce privește condițiile de revocare, codul preia formularea art. 1 alin. (6) din Legea nr. 554/2004²4, arătând că revocarea se poate dispune în cazul în care actul nu a devenit irevocabil prin intrarea în circuitul civil şi dacă nu a produs efecte juridice, adăugând însă suplimentar condiția ca actul să nu poată leza interesul public.

(i) Prima cerință, irevocabilitatea actului, este preluată de art. 26 alin. (2) cu tot cu problemele pe care le ridica art. 1 alin. (6) din Legea nr. 554/2004, mai cu seamă chestiunea semnificației sintagmei „a intra în

23 De altfel, tandemul „legalitate - temeinicie” îl regăsim și în sfera dispozițiilor procedural
civile atunci când ne referim la hotărârile judecătorești: temeinicia este un aspect care ține de
fondul raportului juridic litigios, motiv pentru care ea poate fi analizată decât în primă instanță
sau în căile ordinare de atac, nefiind posibil a fi invocată în căile extraordinare de atac, unde se
pot tranșa doar aspectele de legalitate expres indicate de lege.
24 Potrivit art. 1 alin. (6) din L: 554/2004 „a contenciosului administrativ”, „Autoritatea publică
emitentă a unui act administrativ unilateral nelegal poate să solicite instanței anularea
acestuia, în situația în care actul nu mai poate fi revocat întrucât a intrat în circuitul civil
și a produs efecte juridice [s.n. Ov.P., M.-M. P.]. În cazul admiterii acțiunii, instanța se
pronunță, dacă a fost sesizată prin cererea de chemare în judecată, și asupra validității actelor
juridice încheiate în baza actului administrativ nelegal, precum și asupra efectelor juridice
produse de acestea. Acțiunea poate fi introdusă în termen de un an de la data emiterii actului”. 
circuitul civil"25; toate aceste probleme sunt relevante în practică, în special atunci când se punea problema inadmisibilității acțiunii pentru neurmarea unei proceduri prealabile, reclamantul invocând faptul că actul a intrat în circuitul civil şi a produs efecte juridice, astfel că o asemenea cerere de revocare era inutilă. Întrucât nu au existat criterii de aplicare a art. 1 alin. (6) din Legea nr. 554/2004, soluțiile au variat de la instanță la instanță, rămânând în sarcina doctrinei și jurisprudenței să ofere mai multă claritate asupra sintagmei în cauză. Aşa cum am arătat şi cu alt prilej ${ }^{26}$, se poate discuta despre „intrare în circuitul civil” a unui act administrativ doar în cazul celor individuale (un act normativ nu poate intra în circuitul civil, pentru că el creează doar vocații, nu şi drepturi subiective, apte să fie „tranzacţionate” în „comerț”). În acest context, trebuie subliniat că majoritatea actelor adoptate la nivelul Guvernului sau al organelor administrative subordonate acestuia sunt acte normative, astfel că textul art. 26 alin. (2) are o sferă de aplicabilitate mai redusă (de pildă, ar putea fi folosit în situația în care se revocă un ordin al Prefectului cu caracter individual). În plus faţă de caracterul individual al actului, acesta trebuie să creeze un efect patrimonial, să fi fost dobândit cu bună-credință de beneficiar, dreptul dobândit să fi fost deja tranzacționat, respectiv ca între actul administrativ inițial și cel civil subsecvent să fie o legătură atât de strânsă încât, în temeiul principiului resoluto iure dantis resolvitur iure accipientis, revocarea primului să atragă desființarea celui deal doilea.

(ii) A doua cerință - ca actul să fi produs efecte juridice - este inutilă căci este de esența oricărui act administrativ să producă efecte juridice,

25 Ov. PODARU, op. cit., p. 288-296.

${ }^{26}$ Ibidem., p. 289. 
potrivit art. 2 alin. (1) lit. c) din Legea nr. 554/2004, ,actul administrativ este actul unilateral cu caracter individual sau normativ emis de o autoritate publică, în regim de putere publică, în vederea organizării executării legii sau a executării în concret a legii, care dă naștere, modifică sau stinge raporturi juridice".

(iii) Mai vagă este însă condiția ca actul „să poată leza interesul public”. Pe de o parte, trebuie observat că legiuitorul foloseşte conjuncția „şiı" în construcția sa, ceea ce sugerează faptul că cele trei cerințe sunt cumulative: actul să nu fi intrat în circuitul civil și să nu fi produs efecte juridice şi, suplimentar, să fie apt (susceptibil) să lezeze interesul public. S-ar putea interpreta astfel că un act nelegal, dacă nu este vătămător pentru interesul public, nu ar mai putea fi supus revocării de către Guvern. Pe de altă parte, legiuitorul folosește verbul „,a putea”, ceea ce sugerează că vătămarea interesului public nu s-a produs încă. Această formulare ne poate duce cu gândul la cererea de suspendare reglementată de art. 14 din Legea nr. 554/2004, care poate fi dispusă numai dacă paguba este iminentă, dar care nu s-a produs încă, un act deja executat nemaiputând fi suspendat. Astfel, din formularea textului art. 26 alin. (2) ar reieși că revocarea nu ar mai fi posibilă dacă interesul public ar fi fost deja vătămat, ceea ce, în mod evident, reprezintă un alt neajuns al limbajului utilizat de legiuitorul nostru în Codul administrativ.

4.2 Limbajul impropriu: utilizarea unor noțiuni aparținând altor instituții juridice (vânzarea, închirierea și elementele lor)

Potrivit art. 333 alin. (2) C.adm. (care se referă la actul administrativ prin care se aprobă închirierea bunurilor proprietate publică) „Hotărârea 
prevăzută la alin. (1) cuprinde următoarele elemente: [...] prețul minim al închirierii”".

În materie de închiriere, cu toate că art. 340 alin. (1) lit. a), art. 341 alin. (2) lit. g), respectiv art. 347 alin. (1) lit. b) C.adm..$^{27}$ vorbesc toate de chirie și nivelul acesteia, atunci când tratează hotărârea prin care se aprobă închirierea, art. 333 alin. (2) stabilește că aceasta trebuie să cuprindă prețul minim al închirierii. Or, noțiunea de „preț” este specifică unui contract de vânzare-cumpărare, nu unui contract de închiriere. Consecința acestei formulări inexacte ar putea genera dispute artificiale legate de formarea contractului, putând fi îngreunată astfel o procedură de închiriere a unui bun proprietate publică ori privată a unității administrativ-teritoriale.

\subsection{Ambiguități (aparent) fără sens: sintagma „cel puțin” utilizată în materie de frecvență}

Potrivit art. 133 alin. (1) C.adm., „Consiliul local se întrunește în şedințe ordinare, cel puțin o dată pe lună, la convocarea primarului."

Din punct de vedere gramatical, sintagma „cel puțin o dată pe lună” presupune că trebuie organizată minimum o ședință de consiliu local pe lună (consiliul local trebuind să se întâlnească, cel mai rar, o dată pe lună). Cu toate acestea, regula existentă până la adoptarea codului, raportat și la volumul de activitate al consiliului local, a fost ca ședințele ordinare să fie, cel mai des o dată pe lună, putând exista unele luni (în mod accidental și fără a

\footnotetext{
27 Potrivit art. 340 alin. (1) C.adm. „Criteriile de atribuire a contractului de închiriere sunt: a) cel mai mare nivel al chiriei; [...]”; de asemenea, potrivit art. 341 alin. (2) C.adm., „Anunțul de atribuire trebuie să cuprindă cel puțin următoarele elemente: [...] g) nivelul chiriei;”. În fine, conform art. 347 alin. (1) C.adm., „Autoritățile prevăzute la art. 287 sau titularul dreptului de administrare, după caz, au următoarele drepturi și/sau obligații: [...] b) să încaseze chiria, în conformitate cu dispozițiile contractului de închiriere;. [...]”
} 
se pune în discuție dizolvarea consiliului local) în care consilierii nu se întrunesc în ședință. Prin urmare, textul poate avea două interpretări posibile: minim o ședință pe lună (consiliul să se întrunească cel mai rar o dată pe lună) sau maxim o ședință pe lună (consiliul să se întrunească cel mai des o dată pe lună).

Or, din aceste prevederi, nu rezultă nicicum care a fost voința legiuitorului. Pe de altă parte însă, dacă am utiliza metoda gramaticală ar trebui să ajungem la concluzia că pot exista mai multe şedințe ordinare în fiecare lună. Și atunci, care ar mai fi diferența între ședințele ordinare și cele extraordinare?

4.4 Ambiguități suplimentare cu privire la o instituție deja (suficient de) ambiguă: despre contrasemnătură în dreptul administrativ

Contrasemnătura (unui secretar) se regăsește în două locuri în Codul administrativ: pe de o parte în ceea ce privește deciziile primului-ministru (a), pe de alta în situația actelor administrației publice locale (b).

a) La nivel central, potrivit art. 30 C.adm., „Deciziile primministrului se contrasemnează [s.n. Ov.P., M.-M. P.] de secretarul general al Guvernului".

O chestiune de noutate a codului vizează contrasemnarea deciziilor prim-ministrului de către secretarul general al Guvernului, atribuție care este menţionată expres doar în prevederile art. 30 din cod (care îl privesc în principal pe primul-ministru), nu şi de art. 20 din acelaşi act normativ care, la alin. (4), se mărginește să arate că atribuțiile secretarului general se stabilesc prin hotărâre de Guvern. Dar textul de lege nu stabilește nici rolul contrasemnăturii în procesul emiterii actului administrativ, şi, (cu atât mai puțin), nici consecințele juridice ale încălcării acestei formalități. Textului de 
lege citat mai sus i se poate imputa astfel nu numai un caracter ambiguu, ci și unul lacunar.

b) La nivel local, lucrurile se înfățişează încă şi mai complicat. Astfel, potrivit art. 140 alin. (1) C.adm., „După desfășurarea ședinței, hotărârile consiliului local se semnează de către președintele de şedință şi se contrasemnează, pentru legalitate [s.n. Ov.P., M.-M. P.], de către secretarul general al unității/subdiviziunii administrativ-teritoriale”. Așadar, până aici s-ar părea că e vorba de atribuția de a contrasemna un act administrativ deja emis. Apoi însă, potrivit art. 240 alin. (2) teza a II-a C.adm., „[...] contrasemnarea sau avizarea pentru legalitate [s.n. Ov.P., M.M. P.] [...] angajează răspunderea administrativă, civilă sau penală, după caz, a semnatarilor, în cazul încălcării legii, în raport cu atribuțiile specifice", respectiv art 243 alin. (1) C.adm., „Secretarul general al unităţii/subdiviziunii administrativ-teritoriale îndeplinește, în condițiile legii, următoarele atribuții: a) avizează proiectele de hotărâri şi contrasemnează pentru legalitate [s.n. Ov.P., M.-M. P.] dispozițiile primarului, respectiv ale președintelui consiliului județean, hotărârile consiliului local, respectiv ale consiliului județean, după caz; [...]”. Din cele două texte s-ar părea că, în realitate, secretarul unității administrativ-teritoriale ar avea două atribuții distincte: aceea de a aviza, respectiv cea de a contrasemna, pentru legalitate, actele administrative emise/adoptate la nivel local.

Situația îşi găsește rădăcinile în vechea problemă existentă în prevederile Legii nr. 215/2001 a administrației publice locale (abrogată prin Codul administrativ): astfel, potrivit art. 47 teza I din lege, hotărârile consiliului local se contrasemnau pentru legalitate de către secretar, iar conform art. 117 alin. (1) lit. a) din acelaşi act normativ, secretarul aviza pentru legalitate actele autorităților administrației publice locale. Atât la nivel 
doctrinar ${ }^{28}$, cât și la nivel jurisprudențial, interpretarea coroborată a celor două texte a fost în sensul că, raportat la semnificația intervenției secretarului în procesul decizional - aceea de a informa organul emitent cu privire la legalitatea actului care urmează a fi emis - este absolut necesar ca această intervenție să fie anterioară emiterii actului (pentru că altfel ea nu și-ar atinge scopul), deci anterioară semnării acestuia, fiind exclusă aşadar o „contra”semnătură, de vreme ce, la momentul avizării, prin semnătură, a proiectului de hotărâre ori dispoziție, acesta încă nu era semnat.

Această problemă nu a fost tranşată nici de prevederile Codului administrativ. Astfel, din prevederile art. 240 alin. (2) și 243 alin. (1) reiese că legiuitorul a prevăzut, în sarcina secretarului, două atribuții distincte: de avizare a proiectelor de hotărâri, respectiv de contrasemnare pentru legalitate a dispozițiilor primarului sau președintelui consiliului județean, respectiv a hotărârilor de consiliu local sau județean, putându-i-se antrena răspunderea pentru ambele aceste atribuții. $\mathrm{Cu}$ toate că sunt reglementate distinct, raportat la rolul pe care îl are secretarul, semnătura sa aplicată pe actul administrativ (indiferent de momentul la care s-ar realiza acest lucru) nu poate avea decât semnificația unui aviz consultativ (opinie consultativă) pentru legalitatea acestui act. Alăturarea sintagmei „pentru legalitate” contrasemnăturii conduce la ideea unei analize ex-ante, prealabile emiterii actului, aceasta fiind și interpretarea care reiese din prevederile art. 140 alin. (2) C.adm., secretarul putând emite un punct de vedere cu privire la nelegalitatea proiectului de hotărâre care i-a fost spus analizei. Or, în cazul unei contrasemnături văzută în sensul ei clasic, secretarul ar fi avut

28 Ov. PODARU, op. cit., p. 142-143. 
posibilitatea să oprească intrarea în vigoare a actului, căci lipsa contrasemnăturii lipsește actul de forță executorie.

Desigur, ne putem gândi și la o reglementare redundantă dintr-o prea mare grijă la detalii, respectiv dintr-o neîncredere aproape viscerală a legiuitorului în „aptitudinile” mai puțin onorante ale aleșilor noștri locali: secretarul trebuie să avizeze atât proiectul, mai înainte de semnarea sa, cât şi actul final, care ar putea diferi puțin, în conținut, de proiectul avizat favorabil anterior, pentru că autorul său s-a răzgândit ori şi-a modificat voința în ultimul moment. Doar că, în această situație, stabilirea răspunderii secretarului pentru un act deja emis reprezintă o sarcină anevoioasă.

\section{5 „Hocus-pocus” cu despăgubirea, în materia rezilierii contractului de concesiune: o ambiguitate inserată cu rea-credință}

Potrivit art. 327 alin. (1) C.adm., „Încetarea contractului de concesiune de bunuri proprietate publică poate avea loc în următoarele situații: [...] d) în cazul nerespectării obligațiilor contractuale de către concesionar, prin reziliere de către concedent, cu plata unei despăgubiri [s.n. Ov.P., M.-M. P.] în sarcina concesionarului; e) în cazul nerespectării obligațiilor contractuale de către concedent, prin reziliere de către concesionar; f) la dispariția, dintr-o cauză de forță majoră, a bunului concesionat sau în cazul imposibilității obiective a concesionarului de a-l exploata, prin renunțare, fără plata unei despăgubiri [s.n. Ov.P., M.-M. P.]”. Textul ilustrează un alt caz în care s-a manifestat tăcerea (aparent intenționată) a legiuitorului, generatoare de ambiguitate. Astfel, în materia despăgubirilor generate de încetarea unui contract de concesiune, la lit. d) și e) se poate observa o abordare legală (puțin) diferită în funcție de partea căreia îi aparține culpa încetării contractului: în cazul în care rezilierea este dispusă ca urmare a 
nerespectării obligațiilor contractuale de către concesionar, concedentul este îndreptățit la plata unor daune, textul o arată în mod expres. Nu la fel stau lucrurile în situaţia „,̂n oglindă”, atunci când concedentul este cel care nu şi-a îndeplinit obligațiile contractuale, când legiuitorul nu mai prevede expres că şi concesionarul este îndreptăţit la acordarea unor despăgubiri. Semnificația lipsei reglementării este cu atât mai bizară cu cât, în caz de forță majoră ori imposibilitate obiectivă de exploatare a bunului (renunțarea concesionarului la contract - lit. f), se menționează expres că nu se acordă despăgubiri. Așadar, atunci când a intenționat ca despăgubirile să nu fie acordate, legiuitorul a menționat acest aspect în mod expres. În consecință, din interpretarea coroborată a celor trei prevederi legale și raportat la principiul egalității în fața legii (respectiv la principiile generale ale dreptului civil în materie de reziliere și rezoluțiune ${ }^{29}$ ), calea unei petit în daune ar trebui să-i fie deschisă şi concesionarului, însă modul în care textul a fost reglementat va genera, cu siguranță, discuții în cadrul unui viitor litigiu care are drept obiect încetarea unui contract de concesiune. Modul de abordare al acestei chestiuni ne face să credem că legiuitorul în mod intenționat a omis precizarea acordării daunelor în ipoteza culpei concedentului, în speranța evitării acestei sancțiuni, măcar în unele situații, în diversele situații care se vor ivi în jurisprudență.

29 A se vedea, bunăoară C. STĂTESCU, C. BîRSAN, Drept civil. Teora generală a obligațiilor, Editura All Educational, București, 1998, p. 90; L. Pop, Tratat de drept civil. Obligaţiile. Vol. II. Contractul, Ed. Universul Juridic, București, 2009, p. 728-731. 
4.6 Ambiguități create artificial: schimbarea sensului consacrat (în doctrină și jurisprudență) al unor noțiuni de drept administrativ

La finalul studiului nostru ajungem și la definițiile stabilite în partea introductivă a Codului administrativ. Omnia definitio periculosa est, căci acestea au, între altele, efectul negativ al „,̂ncremenirii” dreptului care, astfel, nu mai poate evolua natural așa cum i-o impune evoluția vieții sociale după care se mulează. Iar dacă aceste definiții mai și bulversează sensurile unor noțiuni, aşa cum sunt ele anterior formate în doctrină ori jurisprudență, utilitatea acestora devine mai mult decât îndoielnică. În continuare vom aborda două asemenea situații.

a) Despre competență și tipurile acesteia. Potrivit art. 5 alin. (1) lit. r) C.adm., prin competență se înțelege „ansamblul atribuțiilor stabilite de lege, care conferă autorităților şi instituțiilor administrației publice drepturi și obligații de a desfăşura, în regim de putere publică și sub propria responsabilitate, $o$ activitate de natură administrativă”. Până aici definiția nu aduce nimic nou. Însă în continuare sunt definite trei tipuri distincte ale acestei noțiuni:

(i) competența delegată - „atribuțiile stabilite prin lege şi transferate, împreună cu resursele financiare corespunzătoare, autorităților administrației publice locale de către autoritățile administrației publice centrale pentru a le exercita în numele și în limitele stabilite de către acestea din urmă” (lit. s);

(ii) competența exclusivă - „atribuțiile stabilite prin lege în mod expres şi limitativ în sarcina autorităților administrației publice locale, pentru realizarea cărora acestea au drept de decizie şi dispun de resursele şi mijloacele necesare" (lit. ș); 
(iii) competența partajată - ,atribuțiile exercitate potrivit legii de autorități ale administrației publice locale, împreună cu alte autorități ale administrației publice, stabilite în mod expres și limitativ, cu stabilirea resurselor financiare şi a limitelor dreptului de decizie pentru fiecare autoritate publică în parte" (lit. t).

Astfel, dacă la nivelul teoriei generale a competenței analizate atât în doctrina noastră, cât și în cea străină ${ }^{30}$ binomul competență exclusivă competență partajată vizează modul de exercitare a competenței (stabilit $a b$ initio de lege) fie de către un singur organ administrativ, fie de mai multe, în comun ori prin scindarea unei anumite atribuții, în vreme ce delegarea de atribuții (în urma căreia apare şi noțiunea de „competență delegată”) reprezintă o modalitate de transfer a exerciţiului acesteia de la organul administrativ care are competența originară la un altul, în condițiile stabilite de lege, Codul administrativ schimbă lucrurile dintr-o dublă perspectivă:

(i) Pe de o parte cele trei noțiuni par a reglementa exclusiv raporturi între autoritățile publice centrale şi cele locale; or, aşa cum am arătat deja, ele sunt considerate de multă vreme ca având un conținut mult mai larg, căci competența exclusivă există ori de câte ori o anumită atribuție poate fi exercitată de un anumit organ administrativ (fără imixtiunea/,ajutorul” altuia), în vreme ce competența delegată și competența partajată sunt vizibile ori de câte ori un organ transmite altuia exercițiul unei atribuții în condițiile legii, respectiv atunci când o anumită atribuție este exercitată de cel puțin

$3^{0}$ Pentru detalii a se vedea Ov. PoDARU, op. cit., p. 96-108 precum și autorii străini indicați la notele de subsol 1 de la p. 98, 2 de la p. 99, respectiv 1-4 de la p. 100.

60 
două autorități diferite care conlucrează la emiterea unui act administrativ (complex) $)^{31}$.

(ii) Pe de altă parte, competența delegată pare chiar că se confundă cu o altă noțiune, cea de descentralizare, definită în art. 5 lit. x): „transferul de competențe administrative și financiare de la nivelul administrației publice centrale la nivelul administrației publice din unitățile administrativ teritoriale, împreună cu resursele financiare necesare exercitării acestora". Or, chiar la nivelul teoriei dreptului administrativ, cele două noțiuni trebuie să fie considerate distincte: dacă delegarea reprezintă transferul (temporar) de atribuții de la un organ administrativ la altul, prin manifestarea de voință a primului, în condițiile prevăzute (permise) expres de lege, transfer valabil până la revocarea delegării de către organul titular al atribuției delegate, descentralizarea ar trebui să constea în transferul (definitiv) impus prin lege autorităților centrale care astfel pierd, în favoarea autorităților locale, exercițiul anumitor atribuții legale. Rămâne de văzut ulterior care a fost intenția legiuitorului nostru cu privire la această problemă.

Coroborând prevederile art. 5 cu cele ale art. 110 din Codul administrativ, reiese faptul că distincțiile pe care le-a făcut legiuitorul în materie de competență se aplică doar la nivelul autorităților publice locale; astfel, competența exclusivă este raportată la atribuțiile stabilite în sarcina autorităților administrației publice locale, competența partajată presupune o scindarea competenței în anumite situații între organele administrației publice locale, iar competența delegată se referă și ea la cazul în care o autoritate publică centrală transferă o atribuție în sarcina autorităților publice locale.

${ }^{31}$ Pentru detalii cu privire la teoria actelor complexe a se vedea ibidem, p. 46-48 precum și autorii străini indicați la nota de subsol 1 de la p. 46. 


\section{b) Despre capacitatea administrativă - un respectat} dinozaur al dreptului administrativ. Potrivit art. 5 alin. (1) lit. o) C.adm., prin capacitate administrativă se înțelege „ansamblul resurselor materiale, financiare, instituționale și umane de care dispune o unitate administrativteritorială, cadrul legal care reglementează domeniul de activitate, precum şi modul în care acestea sunt valorificate în activitatea proprie potrivit competenței stabilite prin lege”.

(i) O turnură... fără sens(!?) Cu toate că, în ce privește dispozițiile generale ale codului, intenția legiuitorului a fost, potrivit unei opinii „din interior", aceea de a reglementa expres noțiuni care până la momentul adoptării nu aveau decât o consacrare doctrinară sau jurisprudențială ${ }^{32}$, unele dintre definiții sunt total diferite față de înțelesul acestor noțiuni în materia dreptului administrativ, cel mai evident exemplu fiind cel al capacității administrative. Integrarea acestei noțiuni în sfera condițiilor de valabilitate a actului administrativ a reprezentat una dintre provocările dreptului administrativ, căci trăsăturile capacității administrative, împrumutate din dreptul civil, nu se pliază întocmai pe modul în care sunt construite şi funcționează organele administrative33. Tocmai din acest motiv, acum zece ani am (re)definit capacitatea administrativă ca fiind aptitudinea abstractă a unui subiect de drept de a exercita puterea publică (prin emiterea de acte administrative), aptitudine care-l transformă în persoană juridică de drept public ${ }^{34}$, iar subsecvent şi indisolubil legată de aceasta, competența -

32 V. VEDINAȘ, Codul administrativ adnotat. Noutăți. Examinare comparativă. Note explicative,
Ed. Universul Juridic, București, 2019, p. 19 .
33 Ov. PoDARU, op. cit., p. 82-93.
34 Am analizat astfel critic opinia Prof. IovăNAȘ care, în anii '70 introducea conceptul de
capacitate administrativă (sau restrânsă) a organelor administrative (fără personalitate 62 
modalitatea de divizare legală a exercițiului capacității administrative. Cu alte cuvinte, capacitatea administrativă este exercitată prin intermediul competenței, determinată prin însumarea atribuțiilor reglementate expres de lege.

Prevederile art. 5 alin. (1) lit. o) C.adm. conferă însă o altă definiție a capacității administrative, complet diferită de cea discutată în doctrină până la acest moment: un ansamblu de resurse materiale, financiare, instituționale şi umane de care dispune o unitate administrativ teritorială, cadrul legal care reglementează domeniul de aplicare, precum şi modul în care acestea sunt valorificate. Așadar, capacitatea administrativă nu mai este o parte a capacităţii juridice - aptitudinea unui subiect de drept de a fi parte într-un raport juridic, ca titular de drepturi și obligații - ci ar părea că reprezintă o parte a patrimoniului unei unități administrativ teritoriale (resursele materiale şi financiare), respectiv persoanele fizice care ocupă funcții publice (resursele umane). Noțiunea capătă un sens mai larg, fiind compusă și din cadrul legal care reglementează domeniul de aplicare al acestor resurse şi modul în care ele sunt valorificate. Exprimarea este, din nou, foarte generală, căci nu arată în concret ce se înțelege prin domeniu de aplicare, respectiv modalitate de valorificare a resurselor.

Dar, mai mult de atât, oare care să fie valoarea pentru jurişti a acestui concept eterogen? Doar dacă nu încercăm să găsim un sens tocmai din ceea ce nu a făcut legiuitorul, refuzând să dea valoare legală conceptului de capacitate administrativă aşa cum a fost el conceput acum câteva decenii de Ilie Iovănaș... va fi ultima noastră preocupare în cuprinsul acestui studiu.

juridică) pentru a justifica la nivel teoretic calitatea procesuală pasivă a acestora în contenciosul administrativ (a se vedea Ov. PODARU, op. cit., p. 84). 
(b) O (posibilă) răstălmăcire pentru găsirea unui sens ... Vom porni această analiză încercând să corelăm această noțiune cu altele cu care are raporturi juridice extrem de apropiate.

Astfel, potrivit art. 96 C.adm., (întitulat „Personalitatea juridică a unităţilor administrativ-teritoriale), acestea „sunt persoane juridice de drept public, cu capacitate juridică deplină şi patrimoniu propriu [s.n. Ov.P., M.-M. P.]"35. (alin. 1). Apoi, potrivit alin. (2), atât ele cât și „subdiviziunile administrativ-teritoriale sunt subiecte juridice de drept fiscal, titulare ale codului de înregistrare fiscală și ale conturilor deschise la unitățile teritoriale de trezorerie, precum și la unitățile bancare”. În fine, alin. (3) stabilește doar consecința juridică firească a principiului de la alin. (1): „Unităţile administrativ-teritoriale sunt titulare ale drepturilor şi obligațiilor ce decurg din contractele privind administrarea bunurilor care aparțin domeniului public şi privat în care acestea sunt parte, precum şi din raporturile cu alte persoane fizice sau juridice, în condițiile legii”.

Altfel spus, fiind persoane juridice de drept public, unitățile administrativ-teritoriale au, pe de o parte, o capacitate juridică de drept privat (civil), „deplină”, adică nelimitată de vreun principiu al specialităţii capacității de folosință specific persoanelor juridice, iar, pe de alta, o capacitate juridică de drept public, căci sunt deținătoare ale puterii publice, exercitate prin intermediul organelor lor administrative. Dimpotrivă, întrucât legea nu o prevede în mod expres, aceste autorități publice locale nu au o asemenea capacitate (nici civilă, nici de drept public).

35 Ca prevedere suplimentară, art. 92 alin. (2) precizează clar: „Comunele pot avea în componența lor mai multe localităţi rurale denumite sate, care nu au personalitate juridică [s.n. Ov.P., M.-M. P.]". 
Pe de altă parte, potrivit art. 109 („Reprezentarea în justiție a unităților administrativ-teritoriale”), „Reprezentarea în justiție a unităților administrativ-teritoriale se asigură de către primar sau de către președintele consiliului județean”. Apoi, potrivit alin. (2), „Primarul sau președintele consiliului județean stă în judecată în calitate de reprezentant legal al unității administrativ-teritoriale, pentru apărarea drepturilor și intereselor legitime ale acesteia, și nu în nume personal 36 "

Ce ne spun toate aceste prevederi legale? Instituie ele o revoluție cu privire la calitatea procesuală pasivă în contenciosul administrativ sau regăsim aici doar o altă ambiguitate a Codului administrativ? Desigur că legiuitorul ar fi putut-o arăta mai clar; însă credem că este un moment bun pentru a abandona conceptul de „capacitate administrativă (restrânsă)” a organelor administrative, concept care le conferă calitate procesuală pasivă în litigiile care au ca obiect acte administrative emise de acestea. Altfel spus, ar trebui abandonată regula (jurisprudențială, poate și doctrinară) după care într-un litigiu de contencios administrativ în care se solicită anularea unui act administrativ ori obligarea unei autorități publice (administrative) la soluționarea unei cereri, calitate procesuală pasivă are organul emitent al actului/competent să soluționeze cererea (char dacă acesta nu are capacitate juridică de drept public ori privat, în temeiul capacităţii administrative/restrânse de care se bucură doctrinar/jurisprudențial), și

$3^{6}$ Două precizări importante aduc și alin. (3), potrivit căruia „Atribuția de reprezentare în justiție poate fi exercitată în numele primarului sau, după caz, al președintelui consiliului județean de către consilierul juridic din aparatul de specialitate ori de către un avocat angajat în condițiile legii”, respectiv alin. (4) după care „Cheltuielile de judecată sau, după caz, despăgubirile stabilite pe baza hotărârilor judecătorești definitive se suportă/se fac venit de la/la bugetul local al unității administrativ-teritoriale. Cheltuielile de judecată cuprind toate sumele cheltuite din bugetul local.” 
înlocuită cu aceea potrivit căreia într-un litigiu de contencios administrativ, indiferent de pretențiile reclamantului, calitate procesuală pasivă poate avea doar o persoană juridică de drept public: cea a cărui origan administrativ a emis actul atacat, respectiv este competent să soluționeze cererea formulată de acesta. Dar, să luăm pe rând ideile care, credem noi, se desprind din prevederile art. 109 C.adm., mai sus citate şi susțin ideea de mai sus:

(i) textul de lege nu trebuie interpretat în sensul că alesul local (ca persoană fizică) nu poate sta în judecată în nume propriu, în situația în care i se solicită daune, căci acceptarea unei asemenea interpretări echivalează implicit cu acceptarea ideii că art. 109 C.adm. a abrogat implicit prevederile art. 16 alin. (1) teza I din Legea nr. 554/2004 a contenciosului administrativ, potrivit cărora „Cererile în justiție prevăzute de prezenta lege pot fi formulate și personal împotriva persoanei care a contribuit la elaborarea, emiterea, adoptarea sau încheierea actului ori, după caz, care se face vinovată de refuzul de a rezolva cererea referitoare la un drept subiectiv sau la un interes legitim, dacă se solicită plata unor despăgubiri pentru prejudiciul cauzat ori pentru întârziere”. Or, o asemenea concluzie nu poate fi primită în niciun caz;

(ii) dimpotrivă, singurul sens rezonabil este acela că primarul/președintele consiliului județean nu poate sta în judecată ca ales local (ca „autoritate” sau „instituție” de drept administrativ) în nume propriu, ci ca reprezentant al unității administrativ-teritoriale, singura entitate care poate avea, deci, calitatea de parte în litigiul în cauză. Mai simplu spus, capacitatea administrativă (restrânsă) nu-i este suficientă primarului/președintelui consiliului județean pentru a putea fi parte într-un litigiu de contencios administrativ, pentru asta $o$ entitate juridică având nevoie de capacitate (personalitate) juridică de drept public; 
(iii) ideea ar trebui extinsă la toate organele administrative locale dar și la cele centrale, dar ca efect al principiului general potrivit căruia capacitatea juridică (materială) atrage după sine capacitatea juridică procesuală, iar nu ca o analogie a prevederii art. 109 alin. (2) care are, în sine, o aplicabilitate strictă, la raporturile pe care le reglementează în mod expres;

(iv) apoi, dacă ne raportăm la prevederile alin. (4) al art. 109, vom constata că este nefiresc să existe o parte într-un litigiu (autoritatea publică emitentă, lipsită de capacitate juridică deplină) care nici să nu poată solicita și nici să nu poată fi obligată la plata cheltuielilor de judecată... Situaţia este astfel inutil de complicată în orice litigiu de contencios administrativ în care, aproape întotdeauna trebuie să existe cel puțin doi pârâți: emitentul și persoana juridică de drept public căreia îi aparține acesta: ministrul şi ministerul, prefectul şi instituția prefectului, consiliul județean ori președintele acestuia şi județul, consiliul local ori primarul şi comuna/orașul/municipiul sunt doar câteva exemple de pârâți în tandem pe care-i cunoaşte jurisprudența. O sursă de cheltuieli judiciare inutile: mai multe citații, mai multe seturi de documente de comunicat etc., în condițiile în care, în cvasitotalitatea cazurilor apărarea este făcută de aceeaşi persoană (consilier juridic ori avocat).

De ce să nu simplificăm lucrurile? De ce să nu considerăm că, prin definirea (aparent inofensivă) a capacității administrative aşa cum e aceasta realizată în Codul administrativ nu s-a pus definitiv capăt conceptului de capacitate administrativă (restrânsă) a organelor administrative aşa cum e acesta cunoscut în doctrina și jurisprudență de aproape jumătate de secol? 


\section{5 Încheiere}

Cele de mai sus sunt doar câteva gânduri legate de exprimările utilizate în Codul administrativ, recent intrat în vigoare. Poate că unele dintre ele n-au fost înțelese bine; poate că altele, ambigue într-adevăr, se vor clarifica în viitorul apropiat prin intervenția doctrinei ori a jurisprudenței; în fine, poate că altele vor fi formulate mult mai bine prin chiar intervenția legiuitorului. Noi n-am intenționat, prin acest studiu, decât să stabilim un punct de plecare în discuțiile și analizele care, cu siguranță, vor urma. 